\title{
Effect of Deoxycholic Acid on Immune Cells - An Immunophenotyping Analysis of Peripheral Blood and Splenic Lymphocytes in CD57 Female Mice
}

\author{
Praveen Kumar Reddy Moole ${ }^{1, *}$, Jagan Mohan Reddy Papireddypalli ${ }^{2}$ \\ 'Department of Pharmacology and Toxicology, Biocon Biologics India Limited, Bangalore, Karnataka, INDIA. \\ 2Department of Biotechnology, Acharya Institute of Technology, Bangalore, Karnataka, INDIA.
}

\begin{abstract}
Background: Deoxycholic acid has been used in Chinese traditional medicine "Niuhuang" that is known to have Immunoregulatory and anti-inflammatory properties. Preliminary evidences have shown that Deoxycholic acid modulates the immune system by way of stimulation and helps in maintaining a disease-free state within an individual. The aim of this study was to investigate the effect of Deoxycholic acid on immunophenotyping analysis of peripheral blood and splenic lymphocytes in CD57 female mice. Methods: Animals were treated with control, 100, 500 and $1000 \mathrm{mg} / \mathrm{kg}$ of Deoxycholic acid for 14 days. The animals were euthanized on Day 15 and blood and intact spleens were collected. The homogenized spleens were collected aseptically and prepared single cell suspension of splenocytes. The whole blood and spleen cells were analyzed by flow cytometry. Results: At $100 \mathrm{mg} / \mathrm{kg}$ and $500 \mathrm{mg} / \mathrm{kg}, 2$-fold increase in total lymphocytes (CD45) and significant increases in lymphocyte (T-cell) population and sub-populations of T-cell (Helper T-cell, Cytotoxic T-cell) were observed. Increased (up to $77 \%$ ) proliferation of B-cells was observed at
\end{abstract}

these doses. Similar trends, but at lesser magnitude as compared to 100 and $500 \mathrm{mg} / \mathrm{kg}$, were observed at $1000 \mathrm{mg} / \mathrm{kg}$, this was due to the toxicity observed at this dose. No treatment related changes in the populations of Lymphocytes of spleen. Conclusion: From the results of the present study, it was suggested that Deoxycholic acid treatment modulates the immune system by activating both cell mediated and humoral immune system.

Key words: Deoxycholic acid, Anti-inflammatory, Immunomodulatory, Helper T-cell, Cytotoxic T-cell and B-cells.

\section{Correspondence}

Dr. Praveen Kumar Reddy Moole

Senior Scientific Manager, Department of Pharmacology and Toxicology, Biocon Biologics India Limited, Bangalore-560100, Karnataka, INDIA.

Phone no: +919663474683

Email: praveenmoolae@gmail.com

DOI: 10.5330/ijpi.2020.4.95

\section{INTRODUCTION}

Deoxycholic acid (DCA) is a secondary bile salt that is a principle ingredient of a Chinese traditional medicine "Niuhuang" that is known to have immunoregulatory and anti-inflammatory properties. ${ }^{[1-3]}$ The intestinal microflora produces secondary bile acids as byproduct of metabolism and DCA is one such bile acid. Liver secretes two primary bile acids namely cholic acid and chenodeoxycholic acid. These primary bile acids are metabolized by intestinal microflora to deoxycholic acid and lithocholic acid respectively. The other secondary bile acids produced by intestinal bacteria are ursodeoxycholic and tauroursodeoxycholic acid. $^{[4]}$

DCA is synthesized in gall bladder and found in all the tissues in human. It is circulated throughout the body in an inactive form. During circulation if it encounters any tumor or inflammation, it converts into active form which induces immune reaction that is beneficial. The immune response induced by DCA is specific and local. Few European publications suggests that the immunostimulant effect of DCA is through an unspecific immune system, mainly through activation of the macrophages. These publications suggests that a sufficient systemic exposure with DCA in the human body incites a positive immune reaction through the unspecific immune system. ${ }^{[5]}$ Immunophenotyping, explains a process used to identify cells, based on the antigen or markers on the surface of the cells. The process is used to characterize and analyze specific type of leukemia and lymphoma by comparing the cancer cell to normal cells of the immune system. ${ }^{[6]}$ Immunophenotyping an assay using commercially available exact fluorescently labelled antibodies, permits for the direct examination of a blood sample by multicolor flow cytometry. Numerous cell types can be identified and quantified in a single blood sample, helping to limit sample volume, which is mostly useful in the rodent species regularly used for preclinical toxicology. Whole blood was stained using markers relevant for each species for the detection and quantitation of T cells, B cells, NK cells, T helper cells and T cytotoxic cells. ${ }^{[7]}$ The objective in the present study was to determine the effect of Deoxycholic acid (DCA) on the immune cell populations by immunophenotyping of peripheral blood and spleen cells, data on specific components of the white blood cell (WBC) population was generated to complement and enhance the data collected in routine haematology analysis.

\section{MATERIALS AND METHODS}

\section{Chemicals and reagents}

Deoxycholic acid (Sigma-Aldrich, USA.), DMEM High Glucose Media (GIBCO, CAT\# 11995), RPMI 1640 (GIBCO, CAT\# 22400), PenicillinStreptomycin (GIBCO, CAT\# 15140), HEPES (GIBCO, CAT\# 15630), Fetal Bovine Serum (FBS) (GIBCO, CAT\# 10082), Teva-Copaxone (US Sourced), Mannitol (Formulation buffer) (SIGMA,CAT\# M4125), 1X PBS (GIBCO, CAT\# 14190), RBC Lysis buffer (SIGMA, CAT\#R7757), Ammonium Chloride (SIGMA, CAT\#A9434), Potassium Bicarbonate 
(SIGMA, CAT\#60339), EDTA (SIGMA, CAT\#E6758), Superblock (Thermo Scientific Pierce, CAT\#37545), CD 3 V500-A (BD, CAT\# 260771), CD 45 Per CP-Cy5.5-A (BD, CAT\# 550994), CD 8 PE-CY7-A (BD, CAT\# 552877), NKp46FITC-A (BD, CAT\# 560156), FMO CD4 PE (BD, CAT\# 553653) and FMO B220 FITC (BD, CAT\# 553087). All other chemicals used in the studies were analytical laboratory grades procured from approved vendor.

\section{Institutional animal ethics committee}

The animal experimentation was carried out according to the guidelines of the "Committee for the Purpose of Control and Supervision of Experiments on Animals" (CPCSEA) and approved by Institutional animal ethical committee (IAEC) and confirmed to national guidelines on "the care and use of laboratory animals" (BIO/IAEC/3263).

\section{Test system}

CD 57 female mice weighing (18-25 g) were obtained from Jackson laboratory and housed three animals per cage with paddy husk as bedding. Animals were housed in a controlled environment, the temperature was maintained in range of $19^{\circ} \mathrm{C}$ to $25^{\circ} \mathrm{C}$, relative humidity in range of 30-70\%, a light/dark cycle of $12 \mathrm{hr}$ each and at least 15 fresh air changes per hour. The animals had access to commercial diet and autoclaved potable water ad libitum. The animals were identified by marking at the tip of tail using a black indelible marker pen.

\section{Dose formulation preparation:}

Required quantity of test item was weighed in a beaker and vehicle $(0.5 \% \mathrm{CMC})$ was added slowly and mixed well by continuous stirring using magnetic stirrer. The contents were transferred to measuring cylinder. Finally, the volume was made up to the required quantity with the $0.5 \% \mathrm{w} / \mathrm{v}$ carboxy methyl cellulose to get desired concentrations of 10,50 and $100 \mathrm{mg} / \mathrm{ml}$ of test item. The homogeneity of dose formulations was maintained by constant stirring using magnetic stirrer during dose formulations administration.

\section{Study design for Immunophenotyping}

The animals were weighed and arranged in ascending order of their body weights. Body weight stratified animals was distributed to different experimental groups. Body weight variation of animals selected for the study did not exceed $\pm 20 \%$ of the mean body weight. Animals were divided in to four groups of three per group and dosed with either control, 100,500 or $1000 \mathrm{mg} / \mathrm{kg}$ of DCA administered to mice by oral gavage at dose of $10 \mathrm{ml} / \mathrm{kg}$ of body weight for 14 days. The dose volume administered was calculated for individual animals on the first day of the treatment and was adjusted according to the most recent body weights. The animals were observed daily for 14 days for clinical signs of toxicity. Body weights were recorded on Day 1, 4, 7, 10 and 14. The animals were euthanized on Day 15 and blood and intact spleens were collected.

\section{Blood collection and Spleen harvest}

Blood samples were collected from all animals on day 15 through retroorbital plexus puncture under mild Isoflurane anaesthesia. Water was provided ad libitum during fasting period. Blood was collected into the tubes containing $\mathrm{K}_{2}$ EDTA for Immunophenotyping of blood. The mice were euthanized on $15^{\text {th }}$ day. Intact spleens were collected from the euthanized mice aseptically and transferred to ice cold $10 \mathrm{~mL}$ DMEM medium with $10 \%$ FBS.
Preparation of single cell suspension of splenocytes

The spleen was homogenized using GentleMACS Dissociator. Spleen was immersed in dissociation buffer and the homogenization was performed using the dissociator. The homogenized material was collected aseptically and passed through $70 \mu \mathrm{m}$ cell strainer. Cell suspension was centrifuged at $1200 \mathrm{rpm}$ for $10 \mathrm{~min}$ at RT. The supernatant was discarded and the pellet was re-suspended in $10 \mathrm{~mL}$ of gentleMACS buffer and centrifuged at $1200 \mathrm{rpm}$ for $5 \mathrm{~min}$ at RT. The supernatant was discarded and the pellet was re-suspended in $1 \mathrm{~mL}$ of RBC lysis buffer and incubated for $3 \mathrm{~min}$ at RT. $10 \mathrm{~mL}$ of complete DMEM medium was added to the suspension and centrifuged at $800 \times \mathrm{g}(1200 \mathrm{rpm})$ for $5 \mathrm{~min}$ at RT. The supernatant was discarded and the pellet was re-suspended in $10 \mathrm{~mL}$ assay medium (RPMI with $10 \%$ FBS). ${ }^{[8]}$

\section{Immunocytochemistry staining of Splenocytes for Flow cytometry}

Aliquot $100 \mu \mathrm{L}$ of splenocyte cells (0.2M) into the bottom of a flow tube. Add $100 \mu \mathrm{L}$ blocking solution (2\% FBS) and incubate for $10 \mathrm{~min}$ on ice. Add recommended volumes of antibodies and incubate on ice for $30 \mathrm{~min}$ in dark. Add $2 \mathrm{ml} \mathrm{PBS}$ and centrifuge at $1500 \mathrm{rpm}$ for $5 \mathrm{~min}$ at $40^{\circ} \mathrm{C}$. Discard the supernatant and suspend the pellet in $0.5 \mathrm{ml}$ ice cold PBS. Store samples refrigerated in dark until analysis. The cells were washed and re-suspended with $400 \mu \mathrm{L}$ of the buffer solution for flow cytometric analysis. Finally, data were acquired and analyzed using multicolor FACS with FACSDiva version 6.1.3 software on BD FACSAria ${ }^{\text {Tx }}$ III (BD Biosciences, CA, US). ${ }^{[9]}$

\section{Immunocytochemistry staining of Whole Blood for Flow cytometry}

Aliquot $100 \mu \mathrm{l}$ of whole blood (with EDTA) into the bottom of a flow tube. Add recommended volumes of antibodies and incubate on ice for $30 \mathrm{~min}$ in dark. Add $2 \mathrm{ml}$ of $1 \mathrm{X}$ RBC lysis buffer (BD Sciences) and incubate at RT for $10 \mathrm{~min}$. Centrifuge at $1500 \mathrm{rpm}$ for $5 \mathrm{~min}$ at $40^{\circ} \mathrm{C}$. Decant the supernatant and wash the pellet with $2 \mathrm{ml}$ of ice cold PBS. Centrifuge at $1500 \mathrm{rpm}$ for $5 \mathrm{~min}$ at $40^{\circ} \mathrm{C}$. Discard the supernatant and suspend the pellet in 500ul ice cold PBS. Store samples refrigerated in dark until analysis. The cells were washed and re-suspended with $400 \mu \mathrm{L}$ of the buffer solution for flow cytometric analysis. Finally, data were acquired and analyzed using multicolor FACS with FACSDiva version 6.1.3 software on BD FACSAria ${ }^{\text {tix }}$ III (BD Biosciences, CA, US). ${ }^{[10]}$

\section{Statistical analysis}

The experimental results are expressed as mean \pm standard deviation. The data was subjected to One Way Analysis of Variance (ANOVA) and the significance of differences between the sample means was calculated by Dunnett's test. Null hypothesis was rejected when $p<0.05$ and alternate hypothesis was accepted. Statistical analysis was performed using Graph Pad prism statistical software (version 1.13).

\section{RESULTS}

\section{Clinical signs}

All the animals were observed daily for clinical signs of toxicity. No treatment related clinical signs were noticed in all the animals

\section{Body weights}

Table 1 shows mean body weights of mice treated with vehicle control and with DCA at 100, 500 and $1000 \mathrm{mg} / \mathrm{kg} /$ day. The body weights were recorded twice weekly i.e., Day 1, 4, 7, 10 and 14. No treatment related effects on body weight were observed up to $500 \mathrm{mg} / \mathrm{kg}$ (Table 1). At 1000 
$\mathrm{mg} / \mathrm{kg}$ mean weight loss up to $9 \%$ with respect to vehicle control, though statistically not significant, was observed.

\section{Effect on immune cells in Blood based on Immunophenotyping}

The FSC (Forward Scatter) and SSC (Side Scatter) gating was employed on granulocytes to isolate lymphocytes. The lymphocyte subsets were isolated with cell surface markers namely, $\mathrm{CD}^{+}$(T lymphocytes), $\mathrm{CD}^{+} /$ $\mathrm{CD}^{+}$(T-helper lymphocytes), $\mathrm{CD}^{+} / \mathrm{CD}^{+}$(T-cytotoxic lymphocytes), B220 BV421+ (B lymphocytes) and NKp46 ${ }^{+}$(NK cells).

Table 2 shows the effect of repeated treatment of DCA on total and sub populations of peripheral blood lymphocytes and total Natural Killer (NK) cells. Treatment with DCA at 100 and $500 \mathrm{mg} / \mathrm{kg}$ resulted in significant $(p<0.05)$ increase in total lymphocytes and total T lymphocyte cell populations. DCA treatment resulted in increase in the population of Helper T-cells $\left(\mathrm{CD}^{+}\right)$and Cytotoxic T-cells $\left(\mathrm{CD} 8^{+}\right)$at 100 and 500 $\mathrm{mg} / \mathrm{kg}$, but significantly $(p<0.05)$ at $500 \mathrm{mg} / \mathrm{kg}$. At $1000 \mathrm{mg} / \mathrm{kg}$, similar trends as described above, but at lower magnitude as compared to 100 and $500 \mathrm{mg} / \mathrm{kg}$ were noticed. The immunomodulatory effects of DCA at $1000 \mathrm{mg} / \mathrm{kg}$ were limited due to toxicity $(1000 \mathrm{mg} / \mathrm{kg}$ was identified as a toxic dose in our previous studies in mice and rats).

Treatment with DCA at 100 and $500 \mathrm{mg} / \mathrm{kg}$ showed an increased trend of B-cell population, but was not statistically significant $(p<0.05)$. No effects were noticed on the NK cell population (Table 2 and Figure 1).

\section{Effect on immune cells in Spleen based on Immunophenotyping}

Similar gating strategy as described in immunophenotyping of peripheral blood was employed in the immunophenotyping of splenocytes.

Table 3 shows the effect of repeated treatment of DCA on total and sub populations of spleen lymphocytes and Natural Killer (NK) cells.
Treatment with DCA did not show any changes in the lymphocyte and NK cell populations of spleen (Table 3 and Figure 2).

\section{DISCUSSION}

In current scenario immunostimulant's are receiving extensive attention and are being applied more extensively in promoting immune health and in treatment of diseases. Extensive amount of data illustrates the efficacy of natural byproducts of human metabolism. Human metabolic byproducts like certain secondary salts of bile acids possess immunostimulatory properties that influences the different players of the immune system at molecular and cellular levels, but in many instances the available information on their mechanism of action is still scarce. ${ }^{[1,12]}$ Today, the extent of spread of most of the epidemics and pandemics is huge mainly due to compromised immune health or compromised immunoregulation. These naturally occurring immunostimulant's can be used as nutrient supplements in food to promote immune health prophylactically. Immunostimulation is a type

Table 1: Summary of Body weights (g).

\begin{tabular}{cccccc}
\hline $\begin{array}{c}\text { Dose } \\
(\mathrm{mg} / \mathrm{kg})\end{array}$ & Day 1 & Day 4 & Day 7 & Day 10 & Day 14 \\
\hline Control & $18.8 \pm 1.25$ & $19.5 \pm 0.97$ & $18.9 \pm 0.92$ & $19.9 \pm 1.32$ & $20.6 \pm 1.28$ \\
100 & $18.7 \pm 0.81$ & $18.8 \pm 0.61$ & $19.1 \pm 1.31$ & $19.3 \pm 0.78$ & $20.3 \pm 1.36$ \\
500 & $18.8 \pm 0.78$ & $19 \pm 0.21$ & $19.6 \pm 0.64$ & $19.7 \pm 0.17$ & $20.5 \pm 0.15$ \\
1000 & $18 \pm 0.7$ & $17.7 \pm 0.17$ & $18.5 \pm 0.61$ & $19.2 \pm 0.83$ & $18.9 \pm 0.75$ \\
\hline
\end{tabular}

Summary of Body weights in grams. Control group $(0.5 \% \mathrm{CMC} ; 10 \mathrm{~mL} / \mathrm{kg})$, Deoxycholic acid (100 mg/kg) group, Deoxycholic acid $(500 \mathrm{mg} / \mathrm{kg}$ ) group and Deoxycholic acid $(1000 \mathrm{mg} / \mathrm{kg})$ group. Data are presented as means \pm Standard deviation; ${ }^{*}$ : Statistically significant than the control group $(p<0.05)$

Table 2: Summary of Blood Immunophenotyping.

\begin{tabular}{cccccccc}
\hline Dose $(\mathrm{mg} / \mathrm{kg})$ & $\mathrm{CD} 45$ & $\mathrm{CD}^{+}$ & $\mathrm{CD}^{-}$ & $\mathrm{CD}^{+}$ & $\mathrm{CD}^{+}$ & B cells & NK Cells \\
\hline Control & $34.91 \pm 6.43$ & $13.51 \pm 2.28$ & $21.18 \pm 6.83$ & $6.37 \pm 1.68$ & $5.55 \pm 1.39$ & $19.64 \pm 7.99$ & $1.14 \pm 1.16$ \\
100 & $62.05 \pm 2.82$ & $25.23 \pm 1.45^{*}$ & $36.5 \pm 3.97$ & $12.39 \pm 2.21$ & $9.81 \pm 0.91$ & $34.36 \pm 3.11$ & $1.71 \pm 0.89$ \\
500 & $69.37 \pm 2.79^{*}$ & $31.63 \pm 2.16^{*}$ & $37.39 \pm 1.55$ & $16.17 \pm 2.69^{*}$ & $12.54 \pm 0.61^{*}$ & $34.81 \pm 1.87$ & $2.06 \pm 0.33$ \\
1000 & $55.85 \pm 2.87$ & $23.35 \pm 5.46$ & $32.27 \pm 3.03$ & $11.7 \pm 3.29$ & $9.07 \pm 2.66$ & $30.43 \pm 3.16$ & $1.39 \pm 0.58$ \\
\hline
\end{tabular}

Summary of blood immunophenotyping parameters. Control group (0.5 \% CMC; $10 \mathrm{~mL} / \mathrm{kg})$, Deoxycholic acid (100 mg/kg) group, Deoxycholic acid $\left(500 \mathrm{mg} / \mathrm{kg}\right.$ ) group and Deoxycholic acid $(1000 \mathrm{mg} / \mathrm{kg})$ group. CD45: Total lymphocytes, CD3 ${ }^{+}$: Total T-lymphocytes, CD3 : Non lymphocytes, CD4+: Helper T lymphocytes, CD8 ${ }^{+}$: Cytotoxic T lymphocytes, B cells: B Lymphocytes, NK cells: Natural killer cells. Data are presented as means \pm Standard deviation; *: Statistically significant than the control group $(p<0.05)$. Data for sub populations $(\mathrm{CD} 3+/-, \mathrm{CD} 4+, \mathrm{CD} 8+, \mathrm{B}$ cells and NK cells) is reported as a percentage of CD45.

Table 3: Summary of Spleen Immunophenotyping.

\begin{tabular}{ccccccccc}
\hline Dose $(\mathrm{mg} / \mathrm{kg})$ & $\mathrm{CD} 45$ & $\mathrm{CD}^{+}$ & $\mathrm{CD}^{-}$ & $\mathrm{CD}^{+}$ & $\mathrm{CD}^{+}$ & B cells $^{+}$ & NK Cells \\
\hline Control & $31.7 \pm 8.17$ & $23.8 \pm 6.21$ & $7.5 \pm 2.89$ & $7.7 \pm 1.5$ & $8.3 \pm 3.19$ & $6.2 \pm 3.05$ & $0.6 \pm 0.19$ \\
100 & $27.9 \pm 3.15$ & $19.4 \pm 0.92$ & $8.1 \pm 2.4$ & $6.5 \pm 1.5$ & $5.7 \pm 0.94$ & $6.7 \pm 1.98$ & \pm 0.34 \\
500 & $28.9 \pm 4.65$ & $20.4 \pm 2.35$ & $8.2 \pm 2.9$ & $7.3 \pm 1.26$ & $7.1 \pm 0.68$ & $6.4 \pm 2.69$ & $0.9 \pm 0.37$ \\
1000 & $32.6 \pm 3.88$ & $22.2 \pm 1.65$ & $10.1 \pm 2.14$ & $7.1 \pm 0.69$ & $7.1 \pm 0.82$ & 1.98 & $0.8 \pm 0.17$ \\
\hline
\end{tabular}

Summary of spleen immunophenotyping parameters. Control group (0.5 \% CMC; $10 \mathrm{~mL} / \mathrm{kg})$, Deoxycholic acid (100 mg/kg) group, Deoxycholic acid $(500 \mathrm{mg} / \mathrm{kg})$ group and Deoxycholic acid $(1000 \mathrm{mg} / \mathrm{kg})$ group. CD45: Total lymphocytes, CD3 ${ }^{+}$: Total T-lymphocytes, CD3: Non lymphocytes, $\mathrm{CD}^{+}$: Cytotoxic T lymphocytes, CD4 ${ }^{+}$Helper T lymphocytes, B cells: B Lymphocytes, NK cells: Natural killer cells. Data are presented as means \pm Standard deviation; ${ }^{*}$ : Statistically significant than the control group $(p<0.05)$. Data for sub populations $\left(\mathrm{CD}^{+/}, \mathrm{CD} 4^{+}, \mathrm{CD} 8^{+}, \mathrm{B}\right.$ cells and NK cells) is reported as a percentage of CD45. 
of immunomodulation that influences the immune system to activate either adaptive immune response that involves $\mathrm{B}$ cells, $\mathrm{T}$ cells and its subsets i.e., $\mathrm{T}$ helper cells and cytotoxic $\mathrm{T}$ cells and/or innate immunity that involves natural killer cells and other immune effector cells. The main objective of this study was to elucidate the immunostimulatory mechanism of action of Deoxycholic acid (DCA) a secondary bile acid. DCA is a metabolic product of deoxycholic acid, a primary bile acid, produced in intestines by intestinal microflora. DCA is naturally in inert form but converts to active form when it encounters any tumor or inflammation during circulation. The active form of DCA has immunomodulatory role. ${ }^{[13]}$ The immunomodulatory effects of DCA were evaluated on a cellular level by examining the effects on $\mathrm{T}$ and $\mathrm{B}$ lymphocytes and NK cells in the peripheral blood and splenocytes of CD57 mice.

In a 28 days repeat dose rat study conducted as part of this work, DCA showed significant increase in absolute lymphocyte counts in peripheral blood. DCA also showed an increased proliferation of mouse splenocytes extracted from mice treated for 14 days. DCA up to $1000 \mathrm{mg} / \mathrm{kg}$ was well tolerated in these studies. The main toxicity related to DCA was anemia (characterized by Red blood cell counts, hemoglobin and hematocrit values) at doses greater than or equal to $1000 \mathrm{mg} / \mathrm{kg}$.

In the study a total of twelve CD57 mice were treated with either vehicle control, 100,500 or $1000 \mathrm{mg} / \mathrm{kg}$ of DCA for 14 days. The peripheral blood and spleens were collected from CD57 mice after the 14 days of treatment. None of the mice treated with DCA died nor showed changes in body weights. There were no signs of toxicity observed at all the doses tested. The primary splenocytes were extracted from the spleens. The peripheral blood and the splenocytes were immunophenotyped for total lymphocytes (CD45), T-cells $\left(\mathrm{CD}^{+}\right)$, NK cells, Helper T-cells $\left(\mathrm{CD} 4^{+}\right)$ and Cytotoxic T-cells $\left(\mathrm{CD}^{+}\right)$through flow cytometry.

Flow cytometry was used to study the effects of DCA on both peripheral $\mathrm{T}$ and $\mathrm{B}$ lymphocytes and their sub-populations. ${ }^{[6]}$ The peripheral blood, when immunophenotyped showed up to 2 -fold increase in Total

Table 4: Immunophenotyped for Lymphocyte (T-cell) population and sub-populations of T-cell in Blood.

\begin{tabular}{ccccc}
\hline Dose $(\mathrm{mg} / \mathrm{kg})$ & $\mathrm{CD} 45$ & $\mathrm{CD}^{+}$ & $\mathrm{CD}^{+}$ & $\mathrm{CD}^{+}$ \\
\hline 100 & $\uparrow 1.8$ folds & $\uparrow 2$ folds & $\uparrow 1.9$ folds & $\uparrow 1.8$ folds \\
500 & $\uparrow 2$ folds & $\uparrow 2.3$ folds & $\uparrow 2.5$ folds & $\uparrow 2.3$ folds \\
1000 & $\uparrow 1.6$ folds & $\uparrow 1.7$ folds & $\uparrow 1.8$ folds & $\uparrow 1.6$ folds \\
\hline
\end{tabular}

Lymphocyte (T-cell) population and sub-populations of T-cell in Blood. Control group (0.5\% CMC; $10 \mathrm{~mL} / \mathrm{kg})$, Deoxycholic acid (100 mg/kg) group, Deoxycholic acid $(500 \mathrm{mg} / \mathrm{kg})$ group and Deoxycholic acid $(1000 \mathrm{mg} / \mathrm{kg})$ group. CD45: Total lymphocytes, $\mathrm{CD}^{+}$: Total T-lymphocytes, CD4 ${ }^{+}$: Helper T lymphocytes, CD8 ${ }^{+}$: Cytotoxic $\mathrm{T}$ lymphocytes. $\uparrow=$ Increase
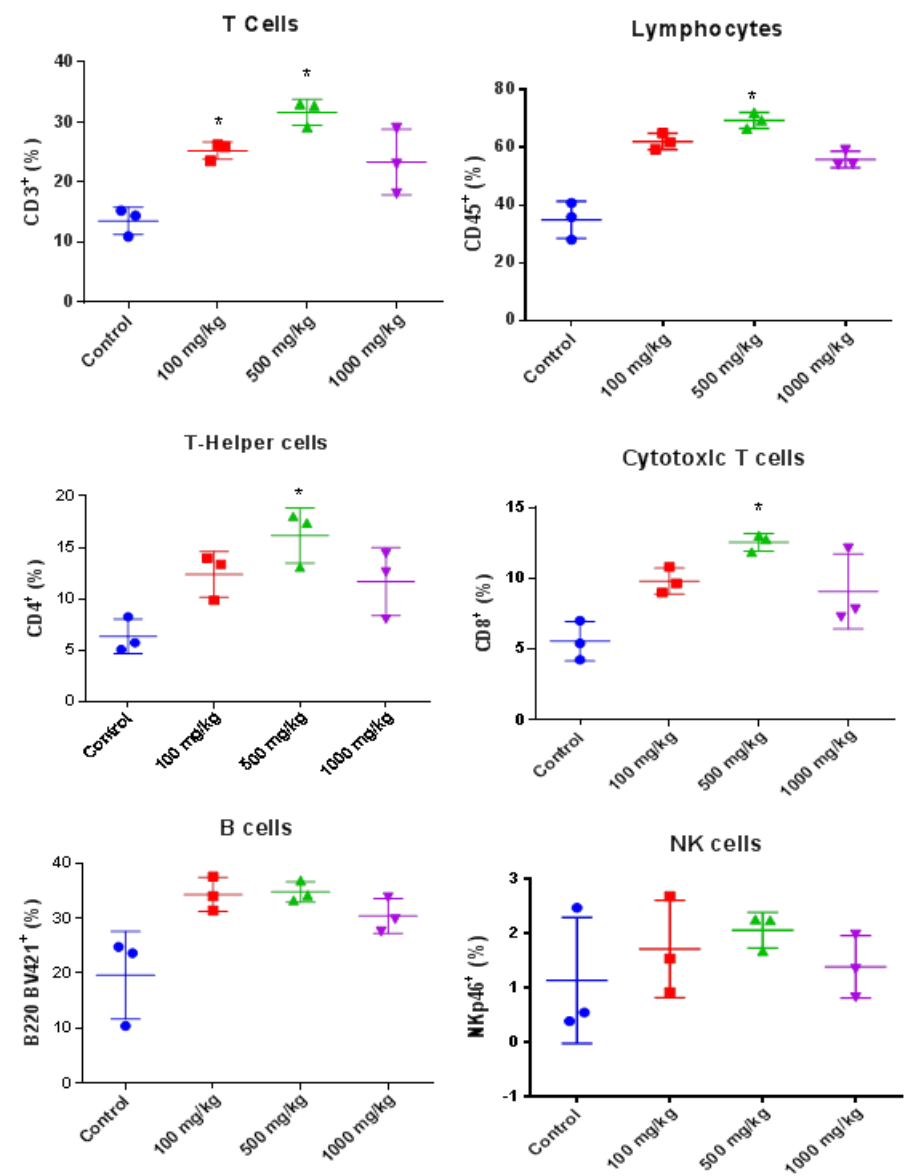

Figure 1: Summary of blood immunophenotyping parameters. Control group (0.5\% CMC; $10 \mathrm{~mL} / \mathrm{kg})$, Deoxycholic acid $(100 \mathrm{mg} / \mathrm{kg})$ group, Deoxycholic acid $(500 \mathrm{mg} / \mathrm{kg})$ group and Deoxycholic acid $(1000 \mathrm{mg} / \mathrm{kg})$ group. Data are presented as means \pm Standard deviation; *: Statistically significant than the control group $(p<0.05)$.
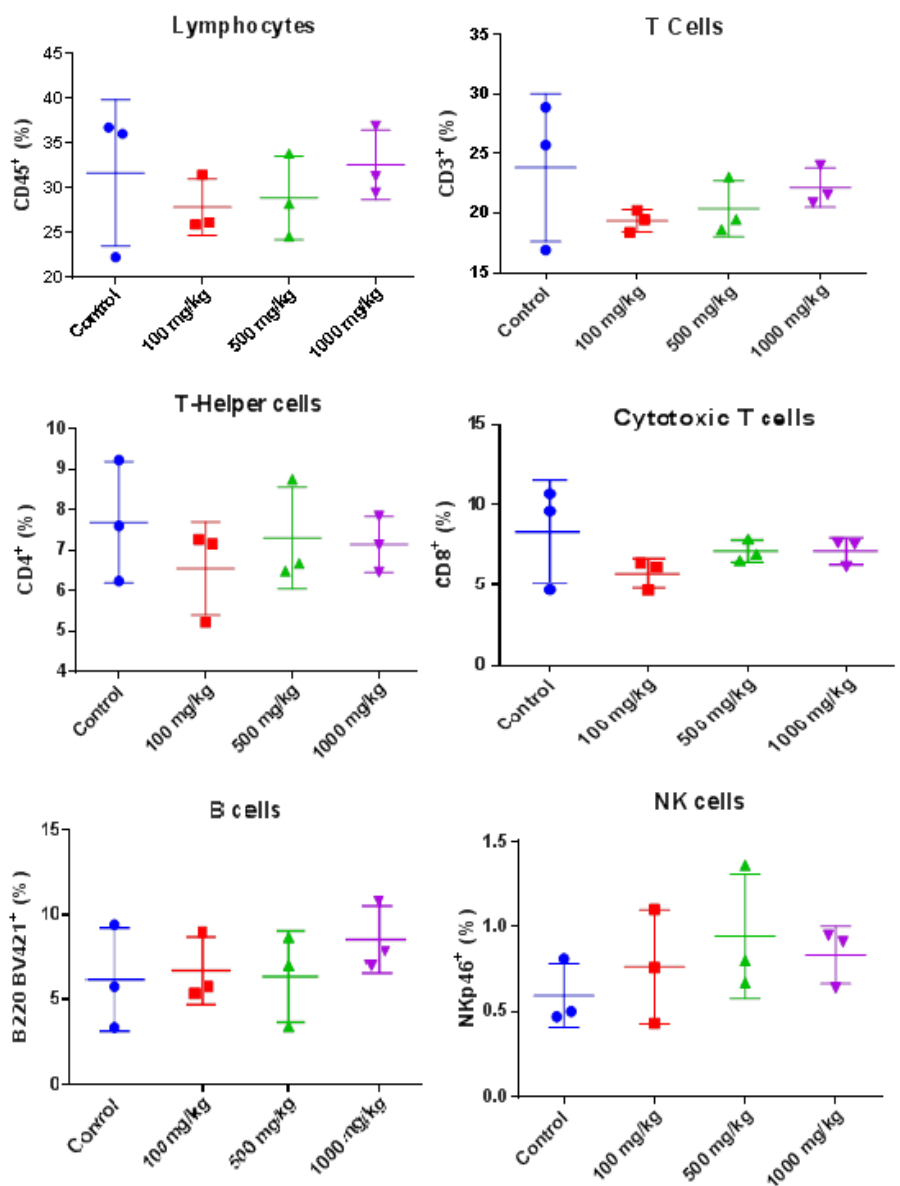

Figure 2: Summary of spleen immunophenotyping parameters. Control group (0.5\% CMC; $10 \mathrm{~mL} / \mathrm{kg})$, Deoxycholic acid (100 mg/kg) group, Deoxycholic acid $(500 \mathrm{mg} / \mathrm{kg})$ group and Deoxycholic acid $(1000 \mathrm{mg} / \mathrm{kg})$ group. Data are presented as means \pm Standard deviation; *: Statistically significant than the control group $(p<0.05)$. 
lymphocytes (CD45), 2.3 folds in T-cells $\left(\mathrm{CD}^{+}\right), 2.5$ folds in Helper T-cells $\left(\mathrm{CD}^{+}\right)$and 2.3 folds in cytotoxic T-cells at $100 \mathrm{mg} / \mathrm{kg}$ and 500 $\mathrm{mg} / \mathrm{kg}$. Treatment with DCA increased the B-cells population up to $77 \%$ at $100 \mathrm{mg} / \mathrm{kg}$ and $500 \mathrm{mg} / \mathrm{kg}$, but was not statistically significant. DCA had positive response on both T-cells and B-cells, however DCA caused significant increases in total T-cells $\left(\mathrm{CD}^{+}\right)$as compared to B-cells. Similar trends, but at lower magnitude as compared to 100 and $500 \mathrm{mg} /$ $\mathrm{kg}$, were noticed at $1000 \mathrm{mg} / \mathrm{kg}$, this was due to the toxicity observed at this dose. DCA showed no effects on NK cell populations (Table 4). DCA has a role in regulating the levels of T regulatory cells (Tregs), the other subsets of T-lymphocyte as reported by Song et al. ${ }^{[14]}$

The Immunophenotyping of cells derived from spleen that were triturated showed no treatment related changes in the populations of either T-cells, B-cells or NK cells

In summary, DCA significantly modulates the cell-mediated immune system as elucidated by increased proliferation T-cells and subpopulation of T-cells. DCA showed effects on the humoral immune system through increased (up to $77 \%$ ) proliferation of B-cells. Even though DCA had stimulant effects on both T-cells (Cell mediated immunity) and B-cells (Humoral Immunity), yet the predominant stimulant effect of DCA was on the T-cells. ${ }^{[15]}$ DCA showed no effects on NK cell populations suggesting a limited role in stimulation of innate immune system.

\section{CONCLUSION}

The immunophenotyping results explained that DCA has significant effects on immune system mainly through activation of $\mathrm{T}$ lymphocytes and also B-cells and no role in innate immune system.

Based on these encouraging results, the investigator is having a future idea to extend the investigations to further preclinical models and conduct clinical trials to assess the potential of using DCA as a nutrient supplement in foods to improve or boost the immune system.

\section{ACKNOWLEDGEMENT}

This work was supported by Bioneeds Laboratory Pvt. Ltd., Biocon Research Limited and Acharya Institute of Technology.

\section{CONFLICT OF INTEREST}

The authors declare no conflict of interests.

\section{ABBREVIATIONS}

DCA: Deoxycholic Acid; CMC: Carboxy Methyl Cellulose; FBS: Fetal Bovine Serum; PBS: Phosphate Buffered Saline; NK: Natural Killer; WBC: White blood cells; ANOVA: Analysis of variance.

\section{REFERENCES}

1. Chen X, Mellon RD, Yang L, Dong H, Oppenheim JJ, Howard OM. Regulatory effects of deoxycholic acid, a component of the anti-inflammatory traditional Chinese medicine Niuhuang, on human leukocyte response to chemoattractants. Biochem Pharmacol. 2002;63(3):533-41.

2. Wang DQ, Carey MC. Therapeutic Uses of Animal Biles in Traditional Chinese Medicine: An Ethnopharmacological, Biophysical Chemical and Medicinal Review. World J Gastroenterol. 2014;20(29):9952-75

3. Fiorucci S, Baldoni M, Ricci P, Zampella A, Distrutti E, Biagioli M. Bile acidactivated receptors and the regulation of macrophages function in metabolic disorders. Curr Opin Pharmacol. 2020;29(53):45-54.

4. Postler TS, Ghosh S. Understanding the Holobiont: How Microbial Metabolites Affect Human Health and Shape the Immune System. Cell Metab. 2017;26(1):110-30.

5. Vlcek B, Reif A, Seidlova B. Evidence of the participation of deoxycholate in cancer immunity. Z Naturforsch. 1971;26(5):419-24.

6. Akanni EO, Palini A. Immunophenotyping of peripheral blood and bone marrow cells by flow cytometry. EJIFCC. 2006;17(1):17-21.

7. Ridge K, Downes N, Finney B. Effects of strain, sex and age on immunophenotyping parameters in the rat and mouse. Comp Clin Pathol. 2019;28(1):41-51.

8. Jungblut M, Oeltze K, Zehnter I, Hasselmann D, Bosio A. Preparation of singlecell suspensions from mouse spleen with the gentleMACS Dissociator. J Vis Exp. 2008;11(22):1029.

9. Yam CS, Hajjar AM. Whole Spleen Flow Cytometry Assay. Bio-protocol. 2013;3(15):e834.

10. Jimenez VE, Chew YV, Nicholson L, Burns H, Anderson P, Chen HT. Standardization of flow cytometry for whole blood immunophenotyping of islet transplant and transplant clinical trial recipients. PLoS One. 2019;14(5):e0217163.

11. Chen ML, Takeda K, Sundrud MS. Emerging roles of bile acids in mucosal immunity and inflammation. Mucosal Immunol. 2019;12(4):851-61.

12. Ma C, Han M, Heinrich B, Fu Q, Zhang Q, Sandhu M, et al. Gut microbiomemediated bile acid metabolism regulates liver cancer via NKT cells. Science. 2018;360(6391):eaan5931.

13. Sipka S, Bruckner G. The Immunomodulatory Role of Bile Acids. Int Arch Allergy Immunol. 2014;165(1):1-8.

14. Song $X$, Sun $X$, Oh SF, Wu M, Zhang $Y$, Zheng $W$, et al. Microbial bile acid metabolites modulate gut $\mathrm{ROR}^{+}$regulatory $\mathrm{T}$ cell homeostasis. Nature. 2020;577(7790):410-15

15. Cano RLE, Lopera HDE. Introduction to T and B lymphocytes. Autoimmunity: From Bench to Bedside. Bogota: El Rosario University Press. Chapter 5.

Article History: Submission Date : 14-09-2020; Revised Date : 11-10-2020; Acceptance Date : 03-11-2020.

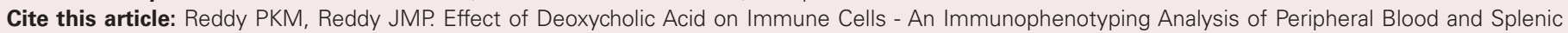
Lymphocytes in CD57 Female Mice. Int. J. Pharm. Investigation, 2020;10(4):548-52. 